\title{
TBCEL Gene
}

National Cancer Institute

\section{Source}

National Cancer Institute. TBCEL Gene. NCI Thesaurus. Code C114421.

This gene is involved in tubulin turnover. 